\title{
ACRL Internship Program
}

The Association of College and Research $\mathrm{Li}$ braries announces the selection of six interns to participate in the first year of its program for administrators of predominantly black college and university libraries. The three-year program, funded by a grant from the Andrew W. Mellon Foundation, is intended to accelerate the development of the management ability of librarians in black colleges and universities by providing them with experience in the administration of strong and progressive academic libraries.

Bernice L. Bell, acting assistant director of libraries and acquisitions librarian at Jackson (Mississippi) State University, and James R. Jarrell, assistant acquisitions librarian at the University of North Carolina at Greensboro, will intern with Herbert F. Johnson, at Oberlin College. Jessie Cottman Smith, director of library services at the University of Maryland, Eastern Shore (in Princess Anne), is assigned to David C. Weber, at Stanford University. Alma Z. McPherson, librarian at Utica (Mississippi) Junior College, will serve her internship with Richard A. Olsen, at Rhode Is- land College. John S. Page, Jr., senior media specialist at Federal City College, and Ida C. Adams, assistant director of university libraries at Florida $\mathrm{A} \& \mathrm{M}$ University, will intern with Richard M. Dougherty, at the University of California, Berkeley.

During the period of the internship, the participants will receive salaries, benefits, and approved expenses from the Mellon Foundation grant. The host institutions will provide the training experience. Several workshops for the participants are also planned.

ACRL is now accepting applications, both from prospective interns and from prospective host institutions, for the second year of the internship program. Ten internships, ranging from three to nine months, will be funded for the $1975 / 76$ academic year.

Deadline for submission of applications from interns and host institutions is December 1 , 1974. For application forms and further information, contact the project director, Casper L. Jordan, Associate Professor, School of Library Service, Atlanta University, Atlanta, GA 30314.
You can get a one year subscription to every priced title in our files for

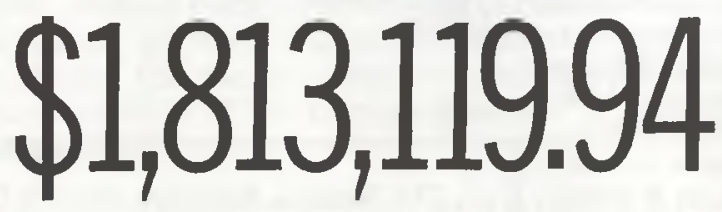

... but our services encompass so much more than just the sale of subscriptions. Our Title Information Department constantly seeks additional information and titles ... our irregular series number in the thousands.

We have a lot more to offer than $\$ 1,813,119.94$ worth of subscriptions! Call or write for full information. (price subject to change, naturally!)

EBSCO SUBSCRIPTION SERVICES division of

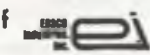

826 South Northwest Highway Barrington. Illinois 60010 (312) 3812190

P. O. Box 2543 Birmingham. Alabama 3520

161 Forbes

16] Forbes Road

Braintree. Mass. 02184
(617) $843-2383$ or $843-2384$

415 Douglas Plaza Building 8226 Douglas Avenue

Dallas. Texas 75225
(214) 3697591 or 3697592

Suite $\$ 10.8$ Diamond Hill Complex 2480 W. 26 th Avenue (303) 4333235 P. O. Box 92901 Los Angeles. California 90009

512 Nicollet Building Minneapolis. Minnesota 55402 (612) 333.5081

EBSCO Building Red Bank. New Jersey 0770 (201) 7414300

681 Market Street San Francisco. Calitornia 94105 (415) 3913500

5406 A Port Royal Road Suite 200

Spring field, Virginia 22151 (D03) 321.7516 or 321.9630

17.19 Washington Avenue Tenafly. New Jersey 07670
(201) 569.2500

Six Thorncliffe Park Drive Toronto, Canada. M4H $1 \mathrm{H}^{3}$ 